\title{
Nestemäiset kierrätyslannoitteet kevätvehnän lannoitteena
}

\author{
Petri Kapuinen \\ Tuotantojärjestelmät, Luonnonvarakeskus, Turku, FINLAND \\ petri.kapuinen@luke.fi
}

\section{TIIVISTELMÄ}

Nestemäisiä kierrätyslannoitteita (NKL) syntyy biolaitoksissa sivutuotteena. Yhden biolaitoksen tuottama määrä riittää tyypillisesti vain yhden kunnan peltojen lannoittamiseen, jolloin rakeistaminen tai kiteyttäminen ei kannata. Paikallisessa käytössä nestemäisyydestä ja hieman pienemmistä ravinnepitoisuuksista ei ole kuitenkaan suurta haittaa.

Yksi NKL:sta on ammoniumsulfaatti (AMS), jota syntyy Suomessa tällä hetkellä Forssassa Envor Goup Oy:n ja Riihimäellä Gasum Oy:n laitoksilla. 35\%:ssa AMS:ssa on 8,9\% N ja 10,2\% S (m/v). Sen tilavuuspaino on $1200 \mathrm{~kg} / \mathrm{m}^{3}$. Lisäksi kiteistä AMS:ia syntyy nikkelin valmistuksen sivutuotteena Harjavallassa huomattava määrä. Suuri $\mathrm{S} / \mathrm{N}$ rajoittaa sen järkevää osuutta $\mathrm{N}$-lannoituksessa. Liian suuri S-annos haittaa kasvin seleeninottoa. $20 \mathrm{~kg} \mathrm{~N} / \mathrm{ha} \mathrm{ja} 23 \mathrm{~kg} \mathrm{~S} /$ ha saadaan noin $225 \mathrm{l} / \mathrm{ha}$ annoksella, mikä on varsin sopiva määrä levitettäväksi kasvinsuojeluruiskulla. Viimeinen käyttömahdollisuus on ruiskutus kasvustoon tähkimisvaiheessa tarkoituksena vehnän valkuaispitoisuuden nosto. AMS:ia voidaan sijoittaa myös nestelannoitusvarusteisella kylvölannoittimella, vaikka $\mathrm{NH}_{3}$-tappioiden puuttuessa sijoitus ei pienenä osuutena N-lannoitusta ole välttämätöntä. AMS:ia käytettäessä päälannoitteessa ei pitäisi olla S:ä, mutta siinä pitäisi olla Se:ä. Kiteistä AMS:ia voi levittää kätevimmin kylvölannoittimen starttilannoitelaatikon kautta osana N-lannoitusta.

Muita hankkeen NKL:ita olivat konsentraatti, typpivesi ja haihduttamalla konsentroitu perunan soluneste. Konsentraatti on haihduttamalla konsentroitua rejektivettä, johon on lisätty rikkihappoa N:n haihtumisen estämiseksi ja siinä N/S-suhde ja oikea käyttöosuus N-lannoituksesta on sama kuin AMS:ssa. Typpivesi (n. $2 \% \mathrm{~N}$ ) on strippaustuote, jossa vastaanottoliuos on vesi. Sen järkevää käyttömäärää ei rajoita rikki. Konsentraatin ja typpiveden levitykseen tarvitaan erikoiskoneita tai se on muuten haasteellisempaa olomuodon tai levitysmäärän takia. Konsentroitu perunan soluneste on lähinnä kaliumlannoite. Konsentroitua perunan solunestettä voi levittää kasvinsuojeluruiskulla levitysmäärän kuitenkin ollessa tälle suuri.

NKL:ien käyttöä kevätvehnä lannoituksessa tutkittiin Kaarinan Yltöisissä vuosina 2017-2018 kenttäkokeessa vertaamalla saatua satoa vastaavalla N-määrällä saatuihin satoihin tavanomaisella rakeisella lannoitteella. NKL:ista oli kokeissa mukana erilaisia käytännön kannalta mielekkäitä käyttötapoja. NKL:t tuottivat $2-21 \%$ (2017) ja $2-11 \%$ (2018) vähemmän satoa kuin tavallinen mineraalilannoite samalla N-määrällä. Konsentraatti osan (n. 20\%) typpi lannoitus ennen kylvöä levitettynä pärjäsi hyvin. Typpivesi toimi varsin hyvin molempina vuosina sen osuuden ollessa puolet $\mathrm{N}$-annoksesta. AMS toimi parhaiten ennen kylvöä ruiskutettuna osana (n. 25\%) N-lannoitusta tai kiteisenä (100\%) kylvön yhteydessä. Konsentroitu perunan soluneste ei toiminut ainoana N:n lähteenä (2017 ja 2018) mutta selvästi paremmin (2018) sen osuuden ollessa puolet N-lannoituksesta.

Asiasanat: ammoniumsulfaatti, konsentraatti, typpivesi, perunan soluneste 


\section{Johdanto}

Nestemäisiä kierrätyslannoitteita tuottavat biolaitokset ovat pääsääntöisesti puhdistamolietettä mädättäviä biokaasulaitoksia, joiden mädätysjäännöksestä erotettua nesteosaa ei saa käyttää lannoitevalmisteena (MMM 2011). Lannoitevalmisteena erotettu nesteosa kuuluisi potentiaalisesti lannoitteisiin kuuluvaan rejektivesi-tyyppinimeen. Lannoitteiden raaka-aineissa puhdistamolietteen osuus saa kuitenkin olla korkeintaan $10 \%$. Nestemäisiä kierrätyslannoitteita syntyy biolaitoksilla useimmiten typenpoiston sivutuotteena, esimerkiksi ammoniumsulfaatti- ja ammoniakkiliuos (typpivesi). Ammoniumsulfaatin (AMS) ja ammoniakkiliuoksen valmistustapa on sellainen, että niillä ei katsota olevan puhdistamolietetaustaa, vaikka niitä tuotetaan puhdistamolietettä mädättävässä biolaitoksessa (Salmela 2018). AMS:ia valmistetaan strippaamalla ammoniakkia ja pesemällä se rikkihapolla. Ammoniakkiliuoksen valmistuksessa pesu tehdään vedellä. Sen typpipitoisuus on selvästi pienempi kuin AMS:in ja pH korkea. Yksittäisen laitoksen tuottamat määrät ovat niin pieniä, että niiden rakeistaminen tai kiteyttäminen ei yleensä kannata. Niiden nestemäisyydestä ei ole logistisessa mielessä suurta haittaa, koska ne voidaan yksittäisen biolaitoksen pienen tuotannon takia käyttää paikallisesti. Tyypillisesti yhden laitoksen tuotantomäärä vastaa yhden kunnan peltoalan lannoituksessa tarvittavaa määrää. Ammoniumsulfaattiliuosta tuotetaan tällä hetkellä Envor Group Oy:n laitoksella Forssassa $4 \mathrm{~m}^{3}$ vuorokaudessa eli $1460 \mathrm{~m}^{3}$ vuodessa enimmäiskapasiteetin ollessa $5 \mathrm{~m}^{3}$ vuorokaudessa eli $1825 \mathrm{~m}^{3}$ vuodessa (https://envor.fi/wp-content/uploads/2017/06/Ammoniumsulfaatti-Tuoteseloste-ID-72.pdf). Lisäksi Suomessa on toinen ammoniumsulfaattia tuottava Gasum Oy:n laitos Riihimäellä. Sen kapasiteetti on $3 \mathrm{~m}^{3}$ vuorokaudessa, mutta tuotanto on ollut varsin ajoittaista. Poikkeuksen yksittäisen laitoksen tuotantomäärästä tekee Harjavallassa Norilsk Nickel Harjavalta Oy:n (https://www.nornickel.fi/) nikkelinvalmistuksen sivutuotteena tuottama kiteinen ammoniumsulfaatti (http://www.ntlmtd.com/product) (https://www.luke.fi/wp-content/uploads/2018/05/Ammoniumsulfaatin-tuotanto-nikkelin-valmistuksen-yhteydessa.pdf). Sen määrä on noin 100000 tonnia vuodessa, ja se riittäisi puolelle Suomen peltoalasta rikkilannoitustarpeen mukaan laskettuna. Pääosa siitä menee vientiin ja markkinoidaan NT Ltd:n (http://www.ntlmtd.com/index) kautta. Maailmanlaajuisesti kuitenkin vain alle 5\% ammoniumsulfaatista syntyy nikkelin ja muiden metallien jalostusprosesseista (Virtanen ja Kinnunen 2019). Selvästi eniten, lähes puolet, sitä tulee nylon 6 -nailonin valmistukseen tarvittavan kaprolaktaamin valmistuksesta. Suurimmat tuottajamaat ovat Yhdysvallat (yli 3 milj. tonnia; 2016) ja Venäjä (1,6 milj. tonnia; 2016). Harjavallan tuotanto on tässä perspektiivissä kuitenkin merkittävä. Sellaisenaan kiteistä ammoniumsulfaattia käytetään Suomessa alle 1000 tonnia vuodessa. Huomattavampi määrä sitä käytetään lannoiteseoksissa.

Ammoniumsulfaatin järkevä käyttömäärä määräytyy rikin perusteella. Kiteisessä ammoniumsulfaatissa on ammoniumtyppeä $21 \%$ ja rikkiä $24 \%$. Rikkilannoitussuositus viljoilla, nurmilla, perunalla ja palkokasveilla on viljavuusrikin olleessa matalakin vain $20-30 \mathrm{~kg} \mathrm{ha}^{-1}$ (Yara 2009), jolloin typpeä tulee noin $20 \mathrm{~kg} \mathrm{ha}^{-1}$. Ristikukkaisilla rikkilannoitussuositus on suurempi, jopa $40-50 \mathrm{~kg} \mathrm{ha}^{-1}$, mikä mahdollistaa suuremman järkevän AMS:in käyttömäärän. Liiallinen rikinkäyttö haittaa kasvien seleeninottoa eikä kierrätyslannoitteissa itsessään yleensä ole seleeniä (Pyörälä ja Tiihonen 2005). Kasvit eivät seleeniä tarvitse, mutta niitä syövät ihmiset ja eläimet kylläkin. Asia on kuitenkin korjattavissa ottamalla ilman seleenilisää olevien lannoitteiden käyttö huomioon ruokinnassa. Seleeniä voidaan lisätä kivennäisaineisiin tai jopa nurmirehun säilöntäaineisiin (Seppälä ym. 2014). Käytettäessä kierrätyslannoitevalmisteita täydennettynä tavanomaisilla rakeisilla lannoitteilla voidaan käyttää karjatiloille tarkoitettuja korkeamman seleenipitoisuuden lannoitteita sadon seleenipitoisuuden turvaamiseksi. $\mathrm{Ne}$ sopivat kuitenkin huonosti käytettäväksi runsaasti rikkiä sisältävien kierrätyslannoitteiden kanssa, koska myös niissä on normaali määrä rikkiä. Ammoniumsulfaatin kanssa käytettäväksi sopii parhaiten lannoite, jossa on seleeniä mutta ei rikkiä.

Esimerkiksi Envor Group Oy:n myymässä 35\%:ssa AMS:ssa on 8,9\% N ja 10,2\% S (m/v) (https://envor.fi/wp-content/uploads/2017/06/Ammoniumsulfaatti-Tuoteseloste-ID-72.pdf). Sen tilavuuspaino on $1200 \mathrm{~kg} \mathrm{~m}^{-3}$, jolloin sen käyttömäärä on noin $2001 \mathrm{ha}^{-1}$. Se sopii hyvin levitettäväksi kasvinsuojeluruiskulla, mutta se voidaan myös sijoittaa nestelannoitusvarusteisella kylvölannoittimella. Tarkoituksenmukaisin tapa kiteisen ammoniumsulfaatin levittämiseen on kylvölannoittimen starttilannoitelaatikko. Koska sen raekoko vaihtelee runsaasti ja joukossa on hyvin pieniäkin kiteitä, levitys 
keskipakoislevittimellä johtaa helposti epätasaiseen levitykseen. Rikin tarpeen mukainen käyttömäärä on noin $100 \mathrm{~kg} \mathrm{ha}^{-1}$. Periaatteessa kiteisen ammoniumsulfaatin voi liuottaa veteen, mutta silloin ongelmana on valmistuksen yhteydessä käytetyt hiilivedyt, jotka kiteytyvät ja tukkivat kasvinsuojeluruiskun suuttimien suodattimet. Suomessa AMS:in käyttöä on tutkittu jonkin verran viljakasveilla kevätkylvöjen yhteydessä ja vehnällä tähkimisvaiheessa valkuaispitoisuuden nostamistarkoituksissa (Tontti ym. 2015, Kapuinen ja Ikäläinen 2016). Tähkimisvaiheen lisätypen anto nimenomaisesti AMS:ina ei ollut antanut kovin hyviä tuloksia (Ervasti ym. 2015, Tontti ym. 2015). Ammoniumsulfaattiliuoksen käyttöä rikkakasvien torjunnan yhteydessä lannoitustarkoituksissa on tutkittu Nesteravinne-hankkeen (www.luke.fi/nesteravinne) osana (https://www.youtube.com/watch?v=1eR3y-2sc w\&feature=youtu.be). Rikkakasvien torjunnan ja lannoituksen yhdistämisellä säästyisi yksi ajokerta. Eräs peruste ammoniumsulfaatin käytölle osana typpilannoitusta on se, että sen avulla voidaan lisätä ammoniumtypen osuutta typpilannoituksessa, mikä vähentää typen huuhtoutumisalttiutta tilanteissa, joissa keväällä on runsaita sateita heti kylvön jälkeen, kun kasvuston typenotto ei heti kylvön jälkeen ole kovin runsasta. Kun fosforilannoitusta on vähennetty, on lannoitteiden fosforipitoisuus laskenut, ja samalla nitraatin osuus lannoitteen typestä kasvanut.

Tässä tutkimuksessa käsiteltävän ammoniakkiliuoksen typpipitoisuus on vain noin $2 \%$. Siinä on vain typpeä, jolloin periaatteessa vaikka koko typpilannoitus voidaan antaa ammoniakkiliuoksena. Käyttömäärä voi tuolloin olla noin $5 \mathrm{~m}^{3} \mathrm{ha}^{-1}$, joka on hyvin hankala maatiloilla yleisesti oleville koneille. Se on liian suuri kasvinsuojeluruiskuille ja liian pieni lietelannan levityslaitteille. Nykyisin Gasum Oy:n tuottama ammoniakkiliuos sisältää ammoniakki noin 15\% (Salmela 2018). Sen käyttömäärä sopii selvästi aikaisempaa versiota paremmin esimerkiksi kasvinsuojeluruiskulla levitettäväksi. Siitä typpeä on $82 \%$, joten sen typpipitoisuus on noin $120 \mathrm{~kg} \mathrm{~m}^{-3}$. Tuotannon määrä on $3000 \mathrm{~m}^{3}$ vuodessa mutta se on kasvamassa $5000 \mathrm{~m}^{3}$ :iin vuodessa. Periaatteessa se riittäisi 3000 - 5000 vehnähehtaarin lannoitukseen. Ammoniakkiliuoksella ei kuitenkaan ole nykyisessä lannoitevalmistelainsäädännössä (MMM 2011) tyyppinimeä, mutta on odotettavissa, että se tulee hyväksytyksi lannoitevalmisteeksi lannoitevalmistelainsäädännön lähivuosien uudistuksen yhteydessä tiukkojen tyyppinimimäärittelyjen poistumisen kautta. Ammoniakki syövyttää voimakkaasti kuparia ja sinkkiä sekä niiden lejeerinkiä messinkiä (Työterveyslaitos 2017), mikä on otettava huomioon levityslaitteiden käytössä. Lisäksi ammoniumsulfaattiliuos ruostuttaa koneita, mikä vähentää viljelijöiden kiinnostusta sen käyttöön.

Joissain tapauksissa nestemäisiä kierrätyslannoitteita syntyy jonkin jakeen konsentroinnin tuloksena, esimerkiksi konsentraatti, joka on konsentroitua rejektivettä, ja konsentroitu perunan soluneste. Konsentraatti on varsin harvinainen, koska valmistustavan takia sen raaka-aineissa ei saa olla yli $10 \%$ puhdistamolietetaustaa. Konsentraatti valmistetaan haihduttamalla rejektivedestä vettä. Siihen lisätään rikkihappoa happamuuden lisäämiseksi, jolla estetään liukoisen typen haihtuminen ammoniakkina. Sen typpipitoisuus on samaa tasoa kuin laimean ammoniakkiliuoksen, mutta siinä on myös muita ravinteita. Tällä hetkellä sitä valmistetaan Suomessa vain Gasumin Vehmaan laitoksella (https://www.gasum.com/Yrityksille/mukaan-kiertotalouteen/kierratyslannoitteet/; Gasum Voimakas Vehmaa). Markkinoilla oleva konsentroitu perunan soluneste on Finnamylin (https://finnamyl.fi/) tuotantoa ja sitä markkinoi tällä hetkellä Soilfood Oy (https://soilfood.fi/) tuotenimellä Boost NPKS. Konsentroitu perunan soluneste valmistetaan konsentroimalla soluneste, joka jää jäljelle tärkkelyksen ja valkuaisen talteenoton jälkeen. Se on lähinnä kaliumlannoite ja tuotantoprosessin takia hapanta. Konsentroitu perunan soluneste soveltuu potentiaalinen runsaasti kaliumia tarvitsevilla kasveille tuotantopaikkojen lähistöllä. Käytännössä tämä tarkoittaa lähinnä perunaa.

Useimmille nestemäisille kierrätyslannoitteille on olemassa teollisia käyttötarkoituksia, kuten eristeteollisuus, vanerin valmistus ja savukaasujen puhdistus, mutta markkinatilanteesta riippuen niitä tarjotaan myös maatalouteen (Virtanen ja Kinnunen 2019). Maatalouskäytön ongelmana on menekin sesonkiluonteisuus. Teollisten käyttömuotojen etu biolaitosten kannalta on tasainen menekki ympäri vuoden. Suurten nestemäisten massojen säilyttämiseen ei ole yleensä niitä käyttävillä maatiloilla varastoja, varsikaan kasvinviljelytiloilla, jotka olisivat potentiaalisia vastaanottajia. Tuotteet varastoidaan yleensä 1000 litran IBC-konteissa. Maataloudessa ravinteiden käyttömäärät ovat niin suuret, että biolaitoksista syntyneiden kierrätyslannoitteiden sisältämät ravinnemäärät voivat kattaa vain hyvin pienen osuuden maatalouden ravinteiden tarpeesta. Ne eivät siten myöskään oleellisesti voi vaikuttaa 
mineraalilannoitteiden markkinoihin, mutta maatalous tarjoaa kestävän käyttökohteen niille silloin, kun teolliset markkinat eivät vedä. Nestemäisten kierrätyslannoitteiden käyttöpotentiaali maataloudessa on huomattavasti suurempi kuin niiden nykyinen tuotanto. Nestemäisten kierrätyslannoitteiden tuotanto niiden itsensä takia ei ole kannattaa, joten tuotanto kasvaa vain, jos biolaitosten typenpoistovaatimukset kasvavat, koska tuotantoprosessi itsessään ei ole kannattava (Ervasti ym. 2015). Niiden valmistus saattaa olla osana biolaitoksen toimintaa taloudellisesti mielekästä esimerkiksi niin, että typenpoistolla voidaan alentaa jätevesimaksuja niin paljon, että jätevesimaksujen alentuminen yhdessä tuotteesta saatavan hinnan kanssa kattaa valmistuskustannuksen. Konsentroitujen nestemäisten lannoitevalmisteiden käyttö on taloudellisesti mielekästä vain suhteellisen lähellä tuotantopaikkaa kuitenkin selvästi kauempana kuin lietelannan ja sitä vastaavien lannoitevalmisteiden, koska pitkät kuljetusmatkat syövät niiden ravinteiden arvon.

Tässä tutkimuksessa selvitettiin ammoniumsulfaatin, ammoniakkiliuoksen, konsentraatin ja perunan konsentroidun solunesteen käyttöä kevätvehnän lannoituksessa. Lannoitteen ja sen käyttötavan hyvyyttä arvioitiin sen typen satovasteella suhteessa vertailulannoitteen vastaavaan.

\section{Aineisto ja menetelmät}

Ensimmäisenä kenttäkoevuonna 2017 ammoniumsulfaattiliuos ruiskutettiin koeruutuihin koeruutukasvinsuojeluruiskulla. Toisena kenttäkoevuotena 2018 se sijoitettiin suorakylvön yhteydessä nestelannoitusvarustuksella olevalla kylvölannoittimella. Kokeen perustamisessa käytettiin Tume NovaCombi 3000 -suorakylvökonetta (Kuva 1). Muutoin nestemäiset kierrätyslannoitteet levitettiin kastelukannuilla letkulevitystä imitoiden, koska käytettävissä ei ollut sopivaa sijoitustekniikkaa. Näin levitetyt lannoitteet mullattiin joustopiikkiäkeällä ruutujen suuntaisesti noin tunnin kuluttua levityksestä. Joustopiikkiäkeessä oli varpajyrä sekä edessä että takana (Potila). Kiteiden ammoniumsulfaatti sijoitettiin kylvön yhteydessä samalla tavalla kuin rakeinen ammoniumnitraattilannoite. Koeruudut olivat ennen lannoitteiden levitystä ja kylvöä muokattu matalaan samaisella joustopiikkiäkeellä poikki koeruutujen niin, että muokkaussyvyys sopi suorakylvötekniikan käyttöön mutta mahdollisti lannoitteen nopean imeytymisen muokkauskerrokseen vähentäen ammoniakkiemissiota ennen multausta.

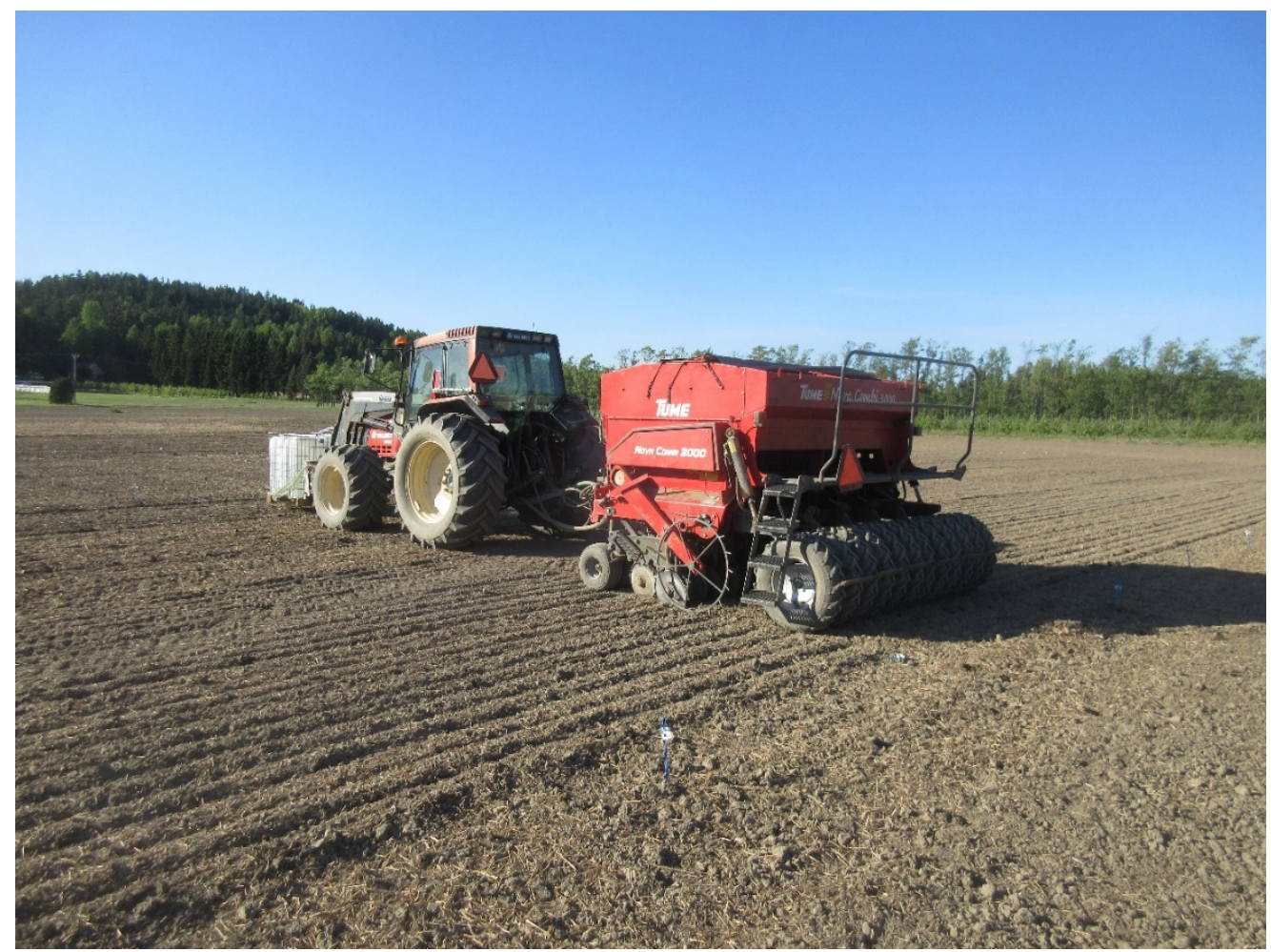

Kuva 1. Kokeiden perustamisessa käytetty nestelannoitusvarusteinen Tume NovaCombi -suorakylvökone 
Kenttäkokeissa oli mukana laimea ammoniakkiliuos (ammoniakkipitoisuus noin 2\%), konsentraatti, ammoniumsulfaatti ja konsentroitu perunan soluneste. Niiden sekä niiden ja vertailulannoitteiden yhdistelmien typpilannoituksen tavoitetaso oli $120 \mathrm{~kg} \mathrm{ha}^{-1}$. Nestemäisiä kierrätyslannoitteita pyrittiin käyttämään tavalla, jotka olisivat tarkoituksenmukaisia vaihtoehtoja niiden käytölle kyseinen lannoite ainoana typen lähteenä tai sitten yhdessä typpitasoissa käytetyn vertailulannoitteen kanssa. Vertailulannoitteen osuus typpilannoituksesta oli suunnittelussa lähtökohtaisesti puolet typpiannoksesta. Kuitenkin konsentraattia ja ammoniumsulfaattia käytettäessä rakeisen vertailulannoitteen osuus oli $90 \mathrm{~kg}$ $\mathrm{ha}^{-1}$, jotta rikkiannos ei kasvaisi kohtuuttomaksi, tai polttovioitusten välttämiseksi. Suuren rikkilannoituksen vaikutuksia tutkittiin käyttämällä yhdessä koejäsenessä pelkkää ammoniumsulfaattikidettä lannoitteena. Kenttäkokeissa toteutetut levitysmäärät laskettiin ennakkonäytteistä määritetyn liukoisen kokonaistypen pitoisuuden perusteella tai jonkin muun ennakkotiedon perusteella. Levityksen yhteydessä otettiin lannoitteista näytteet, joiden analyysitulosten perusteella määritetiin toteutunee typpitasot.

Vuonna 2017 koekasvina oli Wanamo-kevätvehnä (279 kg ha-1, tjp 30,0 g, itävyys 91\%, kylvötiheys $650 \mathrm{kpl} \mathrm{m}^{-2}$ ). Maalaji oli rmHeS (hieta ja karkeammat 27,8\%, hiesu 22,8\% ha saves $49,4 \%$, hehkutushäviö 7,2\%). Fosforiluku oli tyydyttävä $10 \mathrm{mg} \mathrm{l}^{-1}$. Viljavuusfosforin ei voida katsoa olevan tässä tapauksessa sadonmuodostusta rajoittava tekijä. Konsentraatin ja perunan solunesteen mukana tuli vähäinen määrä fosforia. Typpitasoissa $\left(0,30,60,90,120,150 \mathrm{ja} 180 \mathrm{~kg} \mathrm{~N}^{-1}\right)$ käytettiin vuonna 2017 lannoitteena YaraBela Suomensalpietaria (NPKS 27-0-1-4). Konsentraatti levitettiin ennen kylvöä ja kasvustoon kastelukannuilla letkulevitystä matkien. Konsentraatin mukana tuli liukoista kokonaistyppeä 29,9 $\mathrm{kg} \mathrm{ha}^{-1}$, kokonaisfosforia 2,8 $\mathrm{kg} \mathrm{ha}^{-1}$ ja rikkiä 32,8 $\mathrm{kg} \mathrm{ha}^{-1}$ (ennen kylvöä) tai $34,2 \mathrm{~kg} \mathrm{ha}^{-1}$ (kasvustoon). Konsentraatin typpi oli pääasiassa ammoniumtyppeä, jota sen mukana tuli $27,0 \mathrm{~kg} \mathrm{ha}^{-1}$. Kylvölannoituksen yhteydessä konsentraattikäsittelyt saivat typpeä $90 \mathrm{~kg} \mathrm{ha}^{-1}$ YaraBela Suomensalpietarina. Ammoniakkiliuosta levitettiin ennen kylvö joko 4,0 tai 2,0 $\mathrm{m}^{3} \mathrm{ha}^{-1}$. Sen mukana tuli liukoista kokonaistyppeä 90,0 tai 45,0 $\mathrm{kg} \mathrm{ha}^{-1}$, vastaavasti. Pienemmän levitysmäärän tapauksessa kylvön yhteydessä annettiin typpeä YaraBela Suomensalpietarina $60 \mathrm{~kg} \mathrm{ha}^{-1}$. Ammoniumsulfaattia ruiskutettiin ennen kylvöä tai kasvustoon $2001 \mathrm{ha}^{-1}$, jonka mukana tuli ammoniumtyppeä 14,9 kg ha-1 ja rikkiä 15,0 $\mathrm{kg} \mathrm{ha}^{-1}$. Yhtenä vaihtoehtona oli, että kiteistä ammoniumsulfaattia käytettiin kylvön yhteydessä sijoitettuna ainoana lannoitteena. Sen mukana tuli typpeä $120 \mathrm{~kg} \mathrm{ha}^{-1}$ ja rikkiä $137 \mathrm{~kg} \mathrm{ha}^{-1}$, mikä rikkimäärä ylittää selvästi kaikki suositukset. Konsentroidun solunesteen mukana tuli liukoista kokonaistyppeä $22,7 \mathrm{~kg} \mathrm{ha}^{-1}$ ja huomattava määrä kaliumia $102,4 \mathrm{~kg} \mathrm{ha}^{-1}$. Muiden käytettyjen lannoitevalmisteiden mukana tullut kaliumin määrä oli enimmillään $7,3 \mathrm{~kg} \mathrm{ha}^{-1}$. Koealueen viljavuuskalium oli $210 \mathrm{mg} \mathrm{l}^{-1}$ edustaen tyydyttävää tasoa. Kierrätyslannoitteet levitettiin koeruutuihin ennen kylvöä 2. kesäkuuta kuitenkin niin, että kiteinen ammoniumsulfaatti sijoitettiin vasta muiden koeruutujen kylvön jälkeen 3. kesäkuuta. Konsentraatti levitettiin kasvustoon 26. kesäkuuta ja ammoniumsulfaatti ruiskutettiin kasvustoon 27. kesäkuuta. Rikkakasvit torjuttiin 27. kesäkuuta. Kasvunsääde ruiskutettiin 18. heinäkuuta. Koeruudut puitiin 2. lokakuuta. Maanäytteet suurten rikkiannosten vaikutusten viljavuusrikkiin selvittämiseksi ja maalajin määrittämiseksi otettiin seuraavana keväänä.

Vuonna 2018 koekasvina oli Quarna-kevätvehnä (282 $\mathrm{kg} \mathrm{ha}^{-1}$, tjp 37,8 g, itävyys $87 \%, 650 \mathrm{kpl} \mathrm{m}^{-2}$ ). Koe oli samalla peltolohkolla kuin vuonna 2017. Maalaji oli käytännössä sama rmHeS (hieta ja karkeammat $27,2 \%$, hiesu $21,2 \%$, saves 51,5\%, hehkutushäviö 8,2\%). Fosforiluku oli keväällä 2018 keskimäärin 15,1 mg l-1 ja keväällä 2019 keskimäärin 14,1 $\mathrm{mg} \mathrm{l}^{-1}$. Viljavuusfosforin ei voida katsoa olevan tässä tapauksessa sadonmuodostusta rajoittava tekijä. Konsentraatin ja perunan solunesteen mukana tuli vähäinen määrä fosforia, kuten vuonna 2017. Typpitasoissa käytetty lannoite oli Belor Premium Typpi+Se (NPKS 27-0-0-0), millä pyrittiin siihen, että sen mukana tuli seleeniä mutta ei rikkiä. Lannoittamattoman käsittelyn viljavuusrikki oli keväällä $201813,8 \mathrm{mg} \mathrm{l}^{-1}$ ja keväällä $20198,7 \mathrm{mg} \mathrm{l}^{-1}$. Nestemäisillä kierrätyslannoitteilla toteutus oli varsin samanlainen kuin vuonna 2017. AMS-liuosta käytettiin kuitenkin $3001 \mathrm{ha}^{-1}$, jotta typpimäärä olisi ollut sama kuin typpitasossa $120 \mathrm{~kg} \mathrm{ha}^{-1}$. Konsentroidulla perunan solunesteellä toteutettiin vuonna 2018 myös käsittely, jossa osa typestä tuli kylvön yhteydessä sijoitetusta rakeisesta lannoitteesta. Konsentraatilla liukoisen kokonaistypen annos oli ennen kylvöä 32,5 kg ha-1 ja kasvustoon levitettäessä 33,2 $\mathrm{kg} \mathrm{ha}^{-1}$, kylvön yhteydessä sijoitetun typpimäärän ollessa $90 \mathrm{~kg} \mathrm{ha}^{-1}$. Sen mukana tuli rikkiä $24,1 \mathrm{~kg} \mathrm{ha}^{-1}$. Ammoniakkiliuoksella typpimäärät olivat 77,4 ja 98,7 kg ha-1. Jälkimmäisessä on mukana $60 \mathrm{~kg} \mathrm{ha}^{-1}$ kylvön yhteydessä sijoitetun lannoitteen 
typpeä. Käytetyn ammoniakkiliuoksen typpipitoisuus oli selvästi alle ennakoidun. Myös ammoniumsulfaattiliuoksen pitoisuudet olivat alle ennakoidun ja sen mukana tulleeksi typpimääräksi muodostui $21,8 \mathrm{~kg} \mathrm{ha}^{-1}$, jonka lisäksi kylvön yhteydessä sijoitettiin $90 \mathrm{~kg} \mathrm{~N} \mathrm{ha}^{-1}$. Solunestekäsittelyiden typpimäärät olivat 44,6 tai $107,3 \mathrm{~kg} \mathrm{ha}^{-1}$. Jälkimmäisessä on mukana $60 \mathrm{~kg} \mathrm{ha}^{-1}$ kylvön yhteydessä sijoitetun vertailulannoitteen typpeä. Solunesteen mukana tuli rikkimäärä 12,0 tai $24,1 \mathrm{~kg} \mathrm{ha}^{1}$. Kierrätyslannoitteet levitettiin 28. ja 30. toukokuuta kiteistä ammoniumsulfaattia, joka sijoitettiin muiden koeruutujen kylvön jälkeen 31. toukokuuta. Kylvön jälkeen seurasi ankara kuivuus, minkä takia koealue sadetettiin 11. - 12. kesäkuuta. Rikkakasvit torjuttiin 13. heinäkuuta. Kasvunsääteitä ei käytetty kuivuuden takia. Konsentraatti levitettiin ja ammoniumsulfaatti ruiskutettiin kasvustoon 17. heinäkuuta. Lämpimän ja kuivan kesän tuottama sato puintiin koeruuduista jo 10. syyskuuta. Maanäytteet suurten rikkiannosten vaikutusten viljavuusrikkiin selvittämiseksi otettiin välittömästi kylvön jälkeen ja seuraavana keväänä. Maalaji määritettiin samoista näytteistä.

Koeruutujen sato määritettiin 14\%:in kosteudessa. Seleenipitoisuus määritettiin kolmesta käsittelystä: tavoitetaso $120 \mathrm{~kg} \mathrm{~N} \mathrm{ha}^{-1}$ vertailulannoitteena, ammoniumsulfaatti kasvustoon ruiskutettuna ja kiteinen ammoniumsulfaatti kylvön yhteydessä sijoitettuna. Käsittelyiden satoja verrattiin vertailulannoitteen satoon toteutuneilla typpitasoilla. Suuren rikkiannoksen vaikutus sadon seleenipitoisuuteen ja maan viljavuusrikkiin selvitettiin mainituista kolmesta käsittelystä.

\section{Tulokset ja tulosten tarkastelu}

\section{Kasvukausi 2017}

Typpitasoissa sato kasvoi vuonna 2017 selvästi ja lineaarisesti aina typpilannoituksen tavoitetasolle $120 \mathrm{~kg} \mathrm{~N} \mathrm{ha}^{-1}$ (Kuva 2). Satoa tuli typpikilolla lisää 19,56 kg. Sato ei juurikaan kasvanut, kun typpilannoitusta tästä lisättiin. Kierrätyslannoitteiden mukana tullut typpimäärä jäi sopivasti tälle lineaariselle alueelle, mikä helpotti tulosten tulkintaa. Kaikki käsittelyt nestemäisillä kierrätyslannoitevalmisteilla tuottivat samalla typpitasolla pienemmän sadon kuin käytetty vertailulannoite.

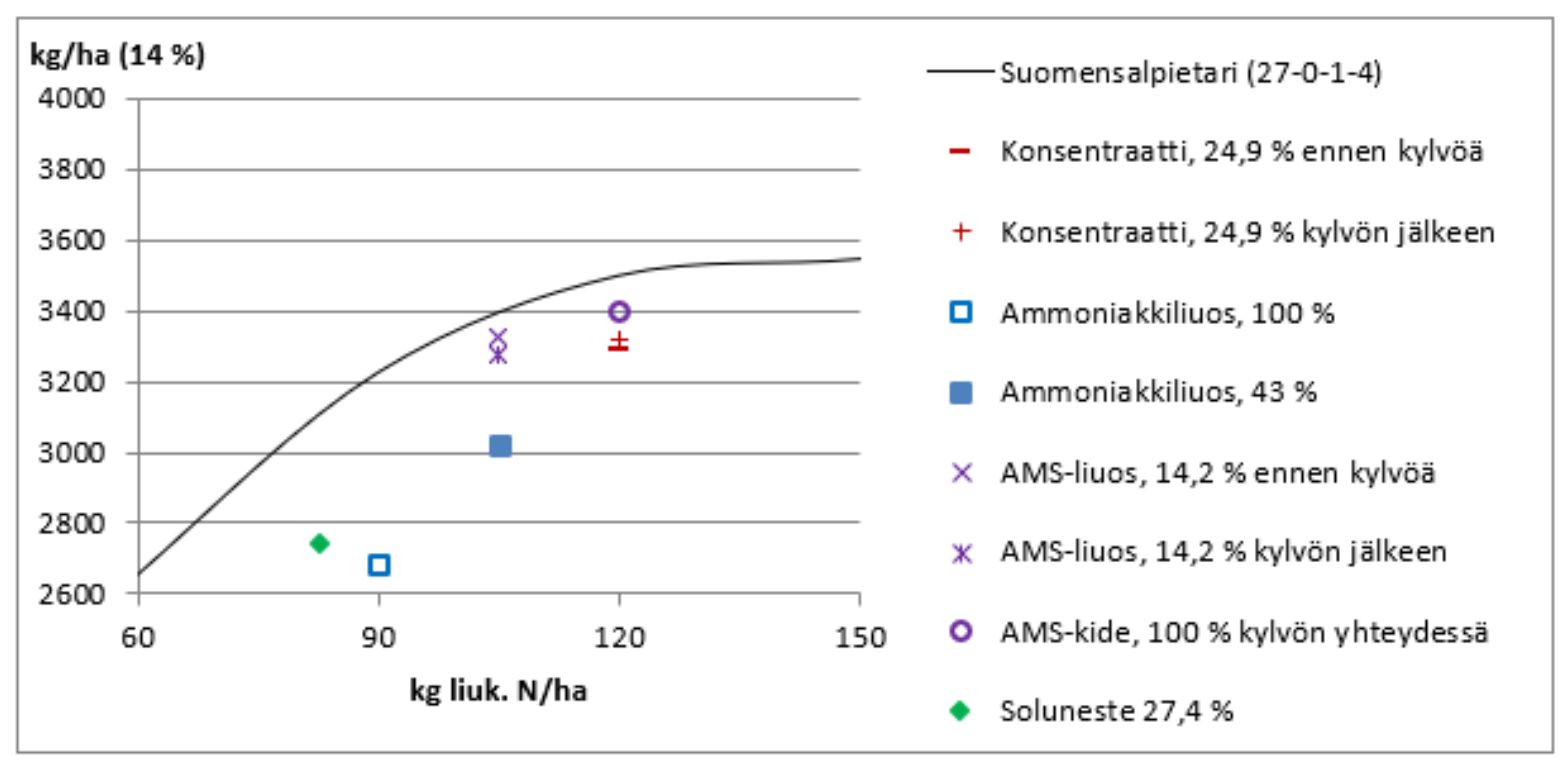

Kuva 2. Sadot 2017

Kun konsentraatti levitettiin kastelukannuilla ennen kylvöä letkulevitystä imitoiden ja kylvön yhteydessä sijoitettiin vertailulannoitteen typpeä $90 \mathrm{~kg} \mathrm{ha}^{-1}$, sato oli 5,9\% pienempi kuin vertailulannoitteella kyseisellä typpimäärällä olisi saatu (Kuva 2). Saatu sato vastasi vertailulannoitteen typpimäärää $95,0 \mathrm{~kg} \mathrm{ha}^{-1}$, joten typen hyväksikäyttö oli sadolla mitaten $20,8 \%$ pienempi kuin pelkkää vertailulannoitetta käyttäen. Kun konsentraatti levitettiin kasvustoon, satovaste oli jonkin verran parempi vastaten satoa, joka oli saatu 97,2 $\mathrm{kg} \mathrm{ha}^{-1}$ vertailulannoitteen typpeä käyttäen. Todellinen konsentraatista ja 
täydennyslannoituksesta saatu typpimäärä oli $119,9 \mathrm{~kg} \mathrm{ha}^{-1}$, joten typen hyväksikäyttö ole sadolla mitaten $18,9 \%$ pienempi kuin pelkällä vertailulannoitteella. Kun näissä koejäsenissä kylvön yhteydessä

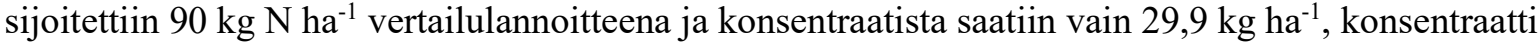
tuotti hyvin vähän lisäsatoa sen lisäksi, mitä näiden käsittelyiden saama vertailulannoite tuotti. Konsentraatin mukana tulleesta typpimäärästä $29,9 \mathrm{~kg} \mathrm{ha}^{-1}$ tuli hyödynnettyä vain 25,1 tai $36,2 \%$ ennen kylvöä tai vasta kasvustoon levitettynä, vastaavasti.

Kun vehnä lannoitettiin pelkällä ammoniakkiliuoksella ennen kylvöä kastelukannuilla levittäen sato vastasi vertailulannoitteen typpimäärää $61,5 \mathrm{~kg} \mathrm{ha}^{-1}$ todellisen annetun typpimäärän ollessa 90,0 kg ha $^{-1}$ (Kuva 2). Saatu sato oli $16,7 \%$ pienempi kuin vertailulannoitteella olisi samalla typpimäärällä saatu. Typen hyväksikäyttö oli siten sadolla mitattuna 68,3\%. Ammoniakkiliuoksen typpipitoisuus oli neljänneksen valmistajalta saatua ennakkotietoa pienempi, jolloin siitä saatu typpimäärä jäi vastaavan määrän tavoitetasoa pienemmäksi. Ammoniakkiliuoksessa oli typpeä vain 1,5\%. Kun ammoniakkiliuoksen levitysmäärä puolitettiin ja kylvön yhteydessä sijoitettiin $60 \mathrm{~kg} \mathrm{~N} \mathrm{ha}^{-1}$ vertailulannoitteena, sato vastasi vertailulannoitteen typpitasoa $77,2 \mathrm{~kg} \mathrm{ha}^{-1}$ todellisen typpimäärän ollessa $105,0 \mathrm{~kg} \mathrm{ha}^{-1}$. Sato oli $11,2 \%$ pienempi kuin tällä määrällä vertailulannoitteen typpeä olisi saatu. Ottaen huomioon se, että tästä $60 \mathrm{~kg} \mathrm{ha}^{-1}$ oli vertailulannoitteena annettua typpeä, itse ammoniakkiliuoksen typen hyväksikäyttö sadolla mitaten oli vain $38,2 \%$.

Kun ammoniumsulfaattiliuos ruiskutettiin ennen kylvöä, saatu sato vastasi vertailulannoitteen typpitasoa $97,8 \mathrm{~kg} \mathrm{ha}^{-1}$ todellisen typpimäärän ollessa $104,9 \mathrm{~kg} \mathrm{ha}^{-1}$ (Kuva 2). Sadon ollessa 3,7\% pienempi kuin vastaavalla määrällä vertailulannoitteen typpeä olisi saatu ja ottaen huomioon, että vehnä sai kylvön yhteydessä vertailulannoitteen typpeä $90 \mathrm{~kg} \mathrm{ha}^{-1}$ sijoitettuna, ruiskutetun ammoniumsulfaatin typen hyväksikäyttö oli vain 52,3\% sadolla mitaten. Kun ammoniumsulfaattiliuos ruiskutettiin kasvustoon, joka oli kylvön yhteydessä saanut $90 \mathrm{~kg} \mathrm{ha}^{-1}$ vertailulannoitteen typpeä, vasta rikkakasvien torjuntavaiheessa, saatu sato vastasi vertailulannoitteen typpitasoa $93,5 \mathrm{~kg} \mathrm{ha}^{-1}$ todellisen typpimäärän ollessa $104,9 \mathrm{~kg} \mathrm{ha}^{-1}$. Sadon ollessa 3,7\% pienempi kuin vastaavalla määrällä pelkkää vertailulannoitteen typpeä olisi saatu ammoniumsulfaattiliuoksen typen hyväksikäyttö sadolla mitaten jäi 24,8\%:iin. Kylvön yhteydessä sijoitetun kiteisen ammoniumsulfaatin tuottama sato vastasi vertailulannoitteen typpitasoa $105,1 \mathrm{~kg} \mathrm{ha}^{-1}$. Kun saatu sato oli 2,8\% pienempi kuin samaisella typpimäärällä $120 \mathrm{~kg} \mathrm{ha}^{-1}$ vertailulannoitteen typpeä olisi saatu, sen typen hyväksikäyttö sadolla mitaten oli $87 \%$.

Kun konsentroitua perunan solunestettä levitettiin ennen kylvöä ja kylvön yhteydessä sijoitettiin $60 \mathrm{~kg}$ $\mathrm{N} \mathrm{ha}^{-1}$ vertailulannoitteena saatu sato vastasi vertailulannoitteen typpitasoa $63,7 \mathrm{~kg} \mathrm{ha}^{-1}$ todellisen typpimäärän ollessa $82,7 \mathrm{~kg} \mathrm{ha}^{-1}$ (Kuva 2). Solunesteestä tuli vain $22,7 \mathrm{~kg} \mathrm{ha}^{-1}$ typpeä. Solunesteen typen hyväksikäyttö jäi 16,3\%:iin sadolla mitattuna. Solunesteen typpipitoisuus poikkesi vahvasti ennakkotiedosta, ja sen mukana tullut typpimäärä jäi noin kolmannekseen tavoitteesta.

Tulosten perusteella nestemäisten kierrätyslannoitteiden typen hyväksikäyttö oli vuonna 2017 yleisesti ottaen varsin heikko. Yllättävän hyvään tulokseen ylsi ammoniakkiliuos. Sillä saatiin nestemäisten kierrätyslannoitteiden sarjassa paras typen hyväksikäyttö sen ollessa vehnän ainoa typpilannoite. Suhteellinen satotappio oli kuitenkin suurempi kuin täydentämällä lannoitusta vertailulannoitteella syntynyt. Selvästi paras typen hyväksikäyttö saatiin kuitenkin käyttämällä vain kiteistä ammoniumsulfaattia.

Maan viljavuusrikki oli seuraavan keväänä peruslannoituksen (120 kg N ha-1 Suomensalpietarina) saa-

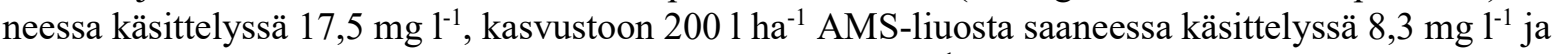
kiteistä ammoniumsulfaattia saaneessa käsittelyssä $12,8 \mathrm{mg} \mathrm{l}^{-1}$. Viljavuusrikin ollessa välttävää tasoa rikkikäsittelyillä oli odotettavissa sadonlisää. Viimeksi mainitulla huomattavan rikkimäärän saaneella käsittelyllä ei ollut enää seuravana keväänä oleellista vaikutusta viljavuusrikkiin. Käsittelyillä oli kuitenkin huomattava vaikutus sadon seleenipitoisuuksiin, jotka olivat vastaavasti $54,1 \mu \mathrm{g} \mathrm{l}^{-1}, 44,3 \mu \mathrm{g} \mathrm{l}^{-1}$ ja $9,0 \mu \mathrm{g} \mathrm{1^{-1 }}$. Suuri rikkimäärä yhdistettynä siihen, että lannoite ei sisältänyt seleeniä laski seleenipitoisuutta oleellisesti. Peruslannoituksen saanut käsittely oli saanut lannoitteen mukana $17,8 \mathrm{~kg} \mathrm{ha}^{-1}$ rikkiä. Vastaavasti ammoniumsulfaattiliuosta saanut käsittely oli saanut rikkiä vertailulannoitteesta $13,3 \mathrm{~kg}$ $\mathrm{ha}^{-1}$ ja ammoniumsulfaatista $15,0 \mathrm{~kg} \mathrm{ha}^{-1}$, yhteensä $28,3 \mathrm{~kg} \mathrm{ha}^{-1}$. Lisäksi se oli saanut neljänneksen 
vähemmän seleeniä kuin peruskäsittely. Pienempi seleenimäärä riittää selittämään pitoisuuden laskun sadossa, mutta myös suuremmalla rikkilannoituksella saattoi olla vaikutusta.

\section{Kasvukausi 2018}

Käytetty vertailulannoitteen typen tuottama sato kasvoi vuonna 2018 lineaarisesti typpitasolle $60 \mathrm{~kg}$ ha $^{-1}$ saakka (Kuva 3). Sen jälkeen typen satovaste taittui jatkaen kasvua lineaarisesti mutta hitaammin. Suuri typen satovaste loppui alemmalla typpitasolla kuin vuonna 2017, mutta sato kasvoi suurilla typpitasoilla enemmän. Satoa tuli typpikilolla lisää $8,18 \mathrm{~kg}$ typpitason ollessa yli $60 \mathrm{~kg} \mathrm{ha}^{-1}$. Typen satovaste tarkastelualueella oli alle puolet siitä, mitä se oli vuonna 2017 . Tavoitetasolla $120 \mathrm{~kg} \mathrm{~N} \mathrm{ha}^{-1}$ sato oli lopulta noin $500 \mathrm{~kg} \mathrm{ha}^{-1}$ suurempia kuin vuonna 2017. Kierrätyslannoitteilla toteutuneet typpitasot osuivat loivemman typen satovasteen alueelle, mutta siitä huolimatta tulkintojen tekeminen on selkeää.

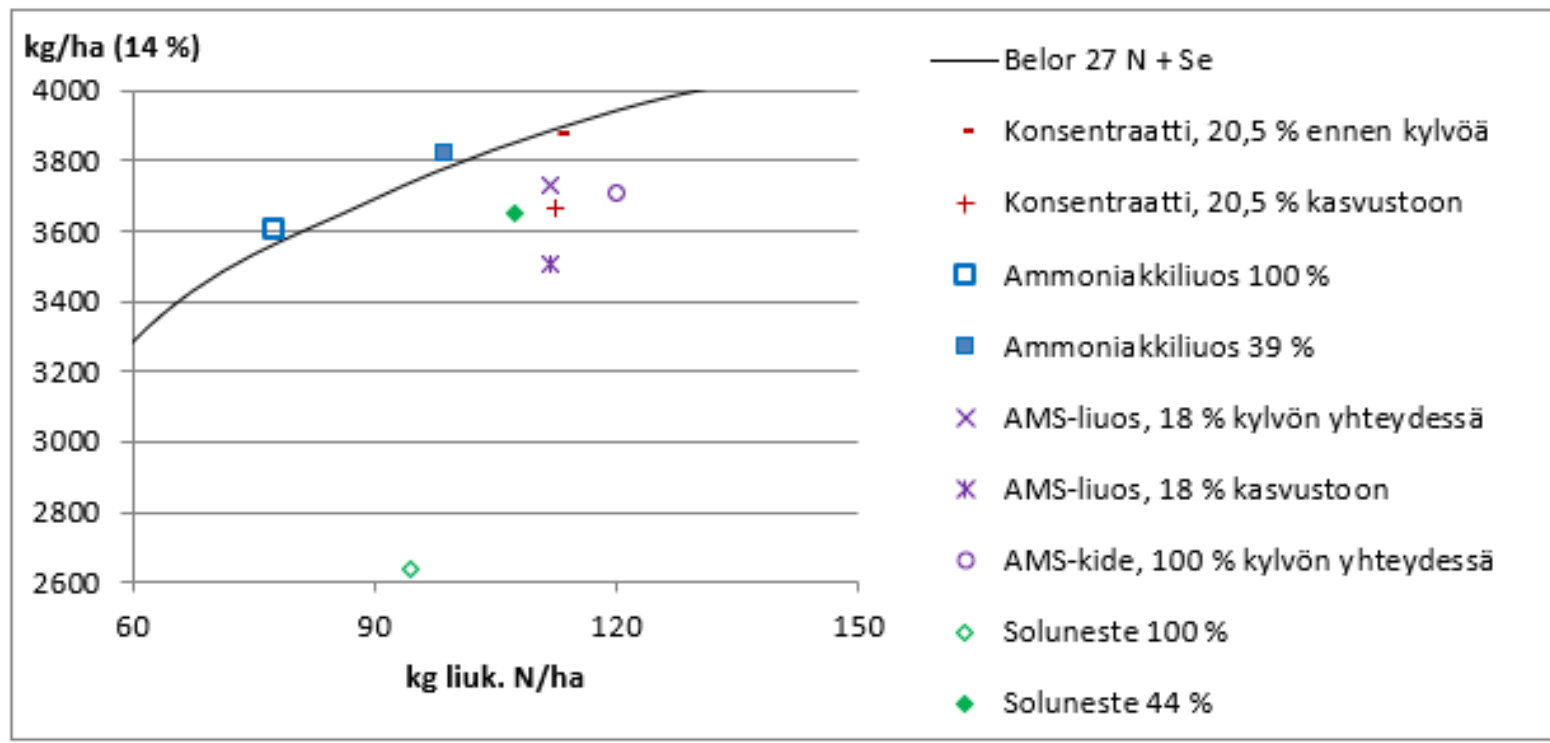

Kuva 3. Sadot 2018

Kun konsentraatti levitettiin ennen kylvöä kastelukannulla letkulevitystä imitoiden ja sen lisäksi, että kylvön yhteydessä sijoitetiin $90 \mathrm{~kg} \mathrm{ha}^{-1}$ typpeä vastaava määrä vertailulannoitetta, käsittely tuotti hieman, $0,6 \%$, alle typpimääräänsä, $113,2 \mathrm{~kg} \mathrm{ha}^{-1}$, vastaavan vertailulannoitteella saatavan sadon (Kuva 3). Sato vastasi vertailulannoitteen typpimäärää $109,8 \mathrm{~kg} \mathrm{ha}^{-1}$, kun konsentraatista tullut typpimäärä oli 20,5\% käsittelyn kokonaismäärästä. Sadolla mitattuna typen hyväksikäyttö oli 97,0\%. Kun konsentraatti levitettiin vasta kasvustoon, sato $\left(3664 \mathrm{~kg} \mathrm{ha}^{-1}\right)$ oli hieman pienempi kuin kylvön yhteydessä 90 $\mathrm{kg} \mathrm{ha}^{-1}$ vertailulannoitteen typpeä saaneen käsittelyn $\left(3687 \mathrm{~kg} \mathrm{ha}^{-1}\right)$. Todellisen typpimäärän mukaiseen satoon vertailulannoitteella satotappio oli $5,8 \%$.

Kun ammoniakkiliuos ennen kylvöä levitettynä oli vehnän ainoa typpilannoitus sato (3612 $\left.\mathrm{kg} \mathrm{ha}^{-1}\right)$ vastasi vertailulannoitteella saatavaa satoa typpitasolla $83,6 \mathrm{~kg} \mathrm{ha}^{-1}$ todellisen typpitason ollessa 77,4 $\mathrm{kg} \mathrm{ha}^{-1}$ (Kuva 3). Käsittely tuotti 2,2\%:n sadonlisän suhteessa typpitasoonsa. Kun ammoniakkiliuoksen annos puolitettiin ja korvatiin $60 \mathrm{~kg} \mathrm{ha}^{-1}$ vertailulannoitteen typpeä kylvön yhteydessä sijoitettuna, sato $\left(3822 \mathrm{~kg} \mathrm{ha}^{-1}\right)$ vastasi vertailulannoitteen typpitasoa $103,9 \mathrm{~kg} \mathrm{ha}^{-1}$ todellisen typpitason ollessa $98,7 \mathrm{~kg} \mathrm{~N}^{-1}$. Sadonlisä oli $1,2 \%$. Kun tämä lasketaan pelkästään ammoniakkiliuoksen hyväksi, sadonlisä sen osuudelle typpilannoituksesta oli 8,5\%.

Sijoitettaessa nestemäinen ammoniumsulfaatti $\left(3001 \mathrm{ha}^{-1}\right)$ kylvön yhteydessä, sen osuuden typpilannoituksesta ollessa $20,5 \%$, saatu sato $3728 \mathrm{~kg} \mathrm{ha}^{-1}$ oli 4,0\% pienempi kuin vertailulannoitteella kyseisellä typpitasolla $111,8 \mathrm{~kg} \mathrm{ha}^{-1}$ saatava (Kuva 3). Sato vastasi vertailulannoitteen typpitasoa 93,9 kg $\mathrm{ha}^{-1}$, jolloin typen hyväksikäyttö sadolla mitattuna oli 84,0\%. Kun ammoniumsulfaatin osuus typpilannoituksesta oli 21,8 $\mathrm{kg} \mathrm{N} \mathrm{ha}^{-1}$ ja sadonlisä siitä vastasi vertailulannoitteen typpimäärää $3,9 \mathrm{~kg} \mathrm{ha}^{-1}$, vain 
17,9\% sen typestä tuli hyödynnettyä. Ammoniumsulfaattiliuoksen $\left(3001 \mathrm{ha}^{-1}\right)$ ruiskuttaminen kasvustoon alensi satoa $4,8 \%$ ilman sitä odotettavissa olevaan nähden. Todellisella typpitasolla vertailulannoitteella saatavaan satoon nähden satotappio oli $6,4 \%$. Kiteisellä ammoniumsulfaatilla saatiin lähes sama satotuloskuin vertailulannoitteella. Sato oli $5,8 \%$ pienempi.

Konsentroitu perunan soluneste tuotti huonosti satoa vehnän ainoana typenlähteenä (Kuva 3). Käsittelyn tuottama sato (2640 $\left.\mathrm{kg} \mathrm{ha}^{-1}\right)$ vastasi $40,7 \mathrm{~kg} \mathrm{~N} \mathrm{ha}^{-1}$ lannoitusta todellisen typpimäärän ollessa 94,6 $\mathrm{kg} \mathrm{ha}^{-1}$. Tällä määrällä vertailulannoitteen typpeä olisi saatu satoa $3735 \mathrm{~kg} \mathrm{ha}^{-1}$, joten satotappio oli $29,3 \%$, ja typen hyväksikäyttö sadolla mitattuna vain $43,0 \%$. Kun solunesteen osuutta typpiannoksesta pienennettiin niin, että se oli 44\% ja lisäksi kylvön yhteydessä sijoitettiin vertailulannoitteen typpeä 60 $\mathrm{kg} \mathrm{ha}^{-1}$, saatu sato (3652 $\mathrm{kg} \mathrm{ha}^{-1}$ ) vastasi $86,9 \mathrm{~kg} \mathrm{~N} \mathrm{ha}^{-1}$ lannoitusta. Todellinen typpimäärä oli 107,3 kg $\mathrm{ha}^{-1}$, jolla vertailulannoitteena olisi saatu $3851 \mathrm{~kg} \mathrm{ha}^{-1}$ vehnää. Satotappio, 5,2\%, merkitsi 81,0\%:n typen hyväksikäyttöä sadolla mitattuna. Kun satotappio kohdistetaan solunesteelle, se oli 34,8\%. Solunesteen typen hyväksikäytöksi tuli sadolla mitattuna 56,8\%.

Nestemäiset kierrätyslannoitteen menestyivät suhteessa vertailulannoitteeseen vuonna 2018 paremmin kuin vuonna 2017. Erityisesti ennen kylvöä levitty konsentraatti tuotti hyvin satoa. Myös ammoniakkiliuos menestyi hyvin ainoan ja yhtenä typen lähteenä. Ammoniumsulfaatti sen sijaan menestyi huonosti vuonna 2018 kasvustoon ruiskutettuna. Analyysitietojen perusteella se oli hyvin hapanta, mikä saattoi olla syynä huomattavaan polttovioitukseen. Konsentroitu perunan soluneste ei menestynyt kovin hyvin myöskään vuonna 2018.

Kiteisen ammoniumsulfaatin mukana keväällä 2018 tullut runsas rikkilannoitus nosti viljavuusrikin lannoittamattoman $13,8 \mathrm{mg} \mathrm{l}^{-1}$ :sta $22,3 \mathrm{mg} \mathrm{l}^{-1}$ een. Vastaavat luvut keväällä 2019 mitattuna olivat 8.7 $\mathrm{mg}^{-1}$ ja 13,8 $\mathrm{mg} \mathrm{l}^{-1}$, joten runsaan rikkilannoituksen vaikutus viljavuusrikkiin heti sen jälkeenkin on melko pieni ja vaikutus vähenee noin puoliin seuraavaan kevääseen mennessä. Rikkilannoituksen vaikutus jyvien seleenipitoisuuteen oli vastaava kuin vuonna 2017. Belor Premium Typpi-lannoitetta käytettäessä typpitason ollessa $120 \mathrm{~kg} \mathrm{ha}^{-1}$, jyvien seleenipitoisuus oli 69,6 $\mathrm{g} \mathrm{l}^{-1}$, AMS-liuoksen ruiskutus kasvustoon johti seleenipitoisuuteen 55,3 $\mu \mathrm{g} \mathrm{l}^{\mathrm{l}^{-1}}$ ja pelkän kiteisen AMS:n käyttö 14,9 $\mu \mathrm{g}^{1^{-1}}$. Seleenipitoisuudet olivat suuremmat kuin vuonna 2017. Ammoniumsulfaattiliuoksen ruikutus kasvustoon johti suhteellisesti yhtä suureen jyvien seleenipitoisuuden laskuun kuin vuonna 2017. Tämä viittaisi siihen, että pienillä rikkilannoitustasoilla seleenipitoisuus riippuu lähinnä seleeniannoksesta, joka myös vuonna 2018 oli neljänneksen pienempi käytettäessä ammoniumsulfaattia kasvustossa.

\section{Johtopäätökset}

Pääsääntöisesti nestemäiset kierrätyslannoitteet tuottivat jonkin verran pienemmän sadon kuin ammoniumnitraattia sisältänyt vertailulannoite. Kaikille nestemäisille kierrätyslannoitteille oli löydettävissä oikea käyttötapa kevätvehnän lannoituksessa, jolla päästiin lähelle vertailulannoitteen satoa, jossain tapauksissa jopa sen yli. Kiteiden ammoniumsulfaatti ainoana typpilähteenä toimi lähes yhtä hyvin kuin ammoniumnitraattilannoite, mutta kuivuus heikensi sillä saatua satoa. Nestemäinen ammoniumsulfaatti on syytä levittää ennen kylvöä, koska kasvustoon levitettynä se alensi satoa ennen kaikkea polttovioituksen takia. Polttovioituksen todennäköinen syy on alhainen $\mathrm{pH}$, joka syntyy helposti liian suuresta rikkihappoannoksesta. Konsentroitu perunan soluneste ei toimi kovin hyvin ainoana typen lähteenä, mutta toimii selvästi paremmin, kun sen osuus on alle puolet typpiannoksesta. Konsentraatti ja jopa ammoniakkiliuos tuottivat hyvin satoa jopa letkulevitystekniikalla levitettynä. Ne toimivat paremmin ennen kylvöä levitettynä ja mullattuna kuin vasta kasvustoon levitettynä. Ammoniumsulfaattiliuoksen käytön mielekkyyttä rajoittaa se, että liiallisen rikkiannoksen välttämiseksi sen typpiannokset jäävät pieniksi. Noin $20 € \mathrm{ha}^{-1}$ arvoisesta lannoituksesta on vaikea löytää säästöjä, vaikka lannoitteen saisi ilmaiseksi, koska työkustannukset lisääntyvät ja koneet ruostuvat eikä siitä ole mitään erityishyötyjä, jos ei tarvita hyvin suuria rikkiannoksia. Kasvustoon levittynä siitä syntyy helposti polttovioitusta, joka voi johtaa satotappioihin. Kiteinen ammoniumsulfaatti toimiin sadonmuodostuksessa lähes yhtä hyvin kuin ammoniumnitraatti. Solunesteellä on paikkansa erikoistuotannossa, jossa tarvitaan runsaasti kaliumia, mutta viljakasvien, kuten vehnän, lannoituksessa sille on vaikea löytää tarkoituksen mukaista käyttöä. 
Nestemäisten kierrätyslannoitteiden määrä markkinoilla ei ole kovin merkittävä. Käytännössä yhden biolaitoksen tuotanto riittäisi vain sen sijaintikunnan peltojen lannoitukseen, ja biolaitoksia on aika harvassa. Vielä harvemmalla on sellaisia typenpoistovaatimuksia, että niiden olisi pakko ryhtyä tuottamaan ammoniumsulfaattia tai ammoniakkiliuosta. Typenpoistovaatimusten oleellinen lisääminen on ainoa keino tuoda näitä kierrätysravinteita markkinoille sellaisia määriä, että niiden hinta muodostuisi maataloutta kiinnostavaksi. Poikkeuksen tästä muodostaa luomukelpoiset tuotteet, kuten konsentroitu perunan soluneste. $10 \%$ :n satotappio satotasolla $4000 \mathrm{~kg} \mathrm{ha}^{-1}$ merkitsee vehnän hinnan ollessa 150 $€ \mathrm{t}^{-1}, 60 € \mathrm{ha}^{-1}$ menetystä. Kun $120 \mathrm{~kg} \mathrm{ha}^{-1}$ lannoitetyppeä maksaa noin $120 € \mathrm{ha}^{-1}$, varsin pienet satotappiot johtavat siihen, että kierrätyslannoitteiden on oltava merkittävästi halvempia, jotta niiden käyttö olisi taloudellisesti kannattavaa.

Teolliset käyttömuodot, joissa näitä ravinnetuotteita otetaan vastaan tasaisesti yhdistelmäkuormina, ovat biolaitosten kannalta edullisimpia kohteita, vaikka ne eivät tuotteista maksaisikaan viljelijöitä enemmän. Käytännössä viljelijän pitäisi saada näitä lannoitevalmisteita selvästi edullisemmin kuin tavallisia rakeisia lannoita, joiden käsittelyyn heillä on valmiit logistiikkaketju ja levityslaitteet sekä osaaminen. Teolliset käyttömuodot ovatkin nielleet pääosan näistä lannoiteväkevyyksisistä ravinnetuotteista, eikä niitä ole oleellisia määriä riittänyt maatalouteen. Lannoitevalmistelainsäädännön vaatimukset maataloudessa käytettäville tuotteille ovat haasteellisia. Tässä mielessä tilanne ei kehittynyt tämän tutkimuksen aikana siihen suuntaan, että tarjonta maatalouteen olisi lisääntynyt, pikemminkin päinvastoin. Kun maatalous markkina-alueena on tuntunut hankalana, vaikka se aluksi miellettiin lähes ainoaksi ravinnetuotteiden käyttäjäksi, kekseliäisyys on löytänyt näille tuotteille uusia käyttötapoja ja niiden luoma kysyntä on ollut viime aikoina riittävä, jotta niiden sisältämien ravinteiden hintataso ei ole laskenut maatalouden kannalta kiinnostavalle. Voidaankin kysyä, miksi nämä ravinnetuotteet pitäisi pyrkiä siirtämään teollisista käyttömuodoista maatalouteen, kun ne tuntuvat sinne paremmin sopivan. Kun maatalouden ravinnekiertoihin on joka tapauksessa tuotava lisätyppeä jostain niin, miksi ei sitten tavanomaisina lannoitteina, joiden typpi sitten aikanaan päätyy näihin ravinnetuotteisiin ja sitä kautta kierrätetään teollisiin käyttömuotoihin. Nähdäkseni tämä olisi parempi järjestely kuin se, että teollisiin käyttömuotoihin käytetään neitseellisiä ravinnetuotteita ja sitten yritetään väkisin saada kierrätysravinteita ujutettua maatalouden ravinnekiertoihin. Toinen näkökulma asiaan on se, että saattaisi olla järkevämpää liittää nämä ravinnevirrat tavallisten rakeisten lannoitteiden ravinnevirtaan niin, että se ei vaatisi muutoksia siihen infrastruktuuriin, joka on rakennettu rakeisia lannoitteita varten. Tämä ei tapahdu ilman sekoitusvelvollisuutta.

Lisäksi kierrätyslannoitteiden pysyminen spesifikaatioissaan, on haaste biolaitoksille ja viljelijöille. Biolaitokset ei välttämättä saa tuotettua lannoitteita, joiden pitoisuudet pysyisivät samoissa rajoissa kuin rakeisissa mineraalilannoitteissa ja mitä lannoitevalmistelainsäädäntö vaatii. Viljelijän kannalta on ensiarvoisen tärkeää tietää lannoitteen ravinne-, erityisesti typpisisältö tarkasti. Viljelijä ei ole taloudellisesti mahdollista analysoida jokaista kontillista tai edes suurempaakaan erää saadakseen tarpeeksi tarkan tiedon typpipitoisuudesta viljelyn kannalta. Tämä ongelma tuli myös kenttäkokeiden yhteydessä, jossa analysointikustannus ei ollut keskeisin ongelma, vaan koeasetelman kannalta tarkoituksenmukainen typpitaso.

\section{Kirjallisuus}

Ervasti, S., Kapuinen, P. \& Winquist, E. 2015. Typpilannoitteiden valmistus lantaperäisistä materiaaleista, TÄSMÄTYPPI. Loppuraportti. 18 s. Viitattu 9.2. 2020.

https://www.google.com/url?sa=t\&rct=j\&q=\&esrc=s\&source=web\&cd=2\&ved=2ahUKEwjKlIfJ0MLnAhVLpIsKHVpkA7QQFjABegQIBBAB\&url=https\%3A\%2F\%2Fwww.ym.fi\%2Fdownload\%2Fnoname\%2F\%257BD1A4BD35-3019-4E88-A81C-F88AED9A1C3B\%257D\%2F117618\&usg=AOvVaw1rxbv9pv-fK1u7LhFFgp-1.

Kapuinen, P. \& Ikäläinen, T. 2016 Biolaitoksen sivutuotteena syntyvä nestemäinen ammoniumnitraatti, ammoniumsulfaatti ja urea kevätvehnän lannoitteena. Suomen Maataloustieteellisen Seuran Tiedote 33.

https://doi.org/10.33354/smst.75139

MMM 2011. Maa- ja metsätalousministeriön asetus lannoitevalmisteista 24: 1-6+ 4 liitettä. Annettu Helsingissä 1. syyskuuta 20114 
Pyörälä, S \& Tiihonen, T. 2005. Vitamiinien ja hivenaineiden puutostilat ja liikasaanti. Nautojen sairaudet. 11. s. https:/www.google.com/url?sa=t\&rct=j\&q=\&esrc=s\&source=web\&cd=7\&ved=2ahUKEwiA1OnZhsTnAhXNioKHe7DCrAQFjAGegQICRAB\&url=https\%3A\%2F\%2Fhelda.helsinki.fi\%2Fbitstream\%2Fhandle\%2F1975\%2F544\%2F07_vitamiinien_ja_hivenaineiden_puutostilat_ja_liikasaanti.pdf\%3Fsequence\%3D13\&usg=AOvVaw2aq2kggd-Y7-Xmg3vzwro0. Viitattu 9.2.2020

Salmela, J. 2018. Biokaasulaitoksilla syntyvät kierrätyslannoitteet tulevaisuudessa. Nesteravinne-seminaari 27.3.2018. Ammatiopisto Livia, Tuorla, Kaarina. Viitattu 9.2.2020. https://www.luke.fi/wp-content/uploads/2018/09/Tuorla-Nesteravinne_2018.pdf

Seppälä, A., Albarran, Y.M., Miettinen, H., Siguero, M.P., Juutinen, E. \& Rinne, M. 2014. Selenium supplementation by addition of sodium selanate with silage additive. Agricultural and Food Science 23: 81-88. https://doi.org/10.23986/afsci.41179

Tontti. T., Kapuinen, P., Orajärvi, J., Joki-Tokola, E., Laurila, M., Ikäläinen, T. Kekkonen, J. \& Veijalainen, A.M. 2015. Orgaanisten lannoitevalmisteiden varastointi, levittäminen ja annostelu. Luonnonvara- ja biotalouden tutkimus 46: 1-79. http://urn.fi/URN:ISBN:978-952-326-092-4

Työterveyslaitos 2017. OVA-ohje: Ammoniakki. Viitattu 8.2.2020

https://www.google.com/url? sa=t\&rct=j\&q=\&esrc=s\&source=web\&cd=1\&cad=rja\&uact=8\&ved=2ahUKEwjSkv2SyMLnAhXHmIsKHYtCAgoQFjAAegQIAhAB\&url=https\%3A\%2F\%2Fwww.ttl.fi\%2Fova\%2Fammoni.pdf\&usg=AOvVaw0RnVWxVmpJ-HDVPadlsTrs

Virtanen, E. \& Kinnunen, O. 2019. Ammoniumsulfaatin markkinaselvitys. Soilfood Oy. 6 s.

Yara 2009. Rikkilannoitus. Yara. Viitattu 8.2.2020.

https:/www.google.com/url?sa=t\&rct=j\&q=\&esrc=s\&source=web\&cd=1\&ved=2ahUKEwi2xsjLy8LnAhVimIsKHTqkCrQQFjAAegQIARAB\&url=https $\% 3 \mathrm{~A} \% 2 \mathrm{~F} \% 2 \mathrm{Fwww}$. farmit.net $\% 2 \mathrm{Fsites} \% 2 \mathrm{Fdefault} \% 2 \mathrm{Ffi}-$ les\%2Fother\%2Fnews\%2FRikkilannoitus.pdf\&usg=AOvVaw3svcQaUzSFZeQVuiYtSLxA 